\title{
DIE BENUTTING VAN AFGETREDE VRYWILLIGE WERKERS DEUR PERSONEEL VAN DIENSSENTRUMS
}

\section{Sanet Jansen van Rensburg, Herman Strydom}

\section{INLEIDING}

Hierdie artikel fokus op personeel van agt dienssentrums vir bejaardes in ' $\mathrm{n}$ radius van 150 kilometers vanaf Potchefstroom. Die resultate ten opsigte van die waarde wat vrywilligers vir die personeel inhou, watter take hulle verrig, wat van die afgetrede vrywilligers verwag word en die eienskappe en vaardighede waaroor ' $n$ personeellid moet beskik wat met die afgetrede vrywilligers werk, word in hierdie artikel bespreek. Hierdie data vorm deel van 'n groter studie naamlik om ' $n$ program te ontwikkel en te evalueer om personeel van dienssentrums in bemagtigingsprogramme te betrek wat behoeftegesentreerd is.

\section{PROBLEEMSTELLING}

Volgens die wêreldsensus van 2009, is daar 743 miljoen persone (wat 10.9\% verteenwoordig) ouer as 60 jaar uit $n$ populasie van 6.7 biljoen in die wêreld. Daar word voorspel dat die persentasie persone ouer as 60 jaar na $22.1 \%$ gaan verhoog in die jaar 2050 (United States Census Bureau, 2009). Die 2001 sensus (Statistics South Africa, 2001) bevestig dat daar 7.3\% (3.28 miljoen persone) uit ' $n$ populasie van 44.8 miljoen persone ouer as 60 jaar in Suid-Afrika is. Dus 'n groei van 0.4\% vanaf die 1996 sensus (Department of Social Development, 2005:11).

Ntusi en Ferreira (2004:3) voorspel dat 80 jariges en ouer persone se persentasie van $8 \%$ van die bevolking in 2002 na $19 \%$ in 2050 gaan verdubbel. In die Noordwes Provinsie was daar in $19967.9 \%$ persone ouer as 60 jaar (224 010 persone) teenoor 2001 se 8.2\% (269 500 persone), dus ' $\mathrm{n}$ groei van 0.3\% (45 490 persone) in 4 jaar. As gevolg van vroeë aftrede, is jong afgetredenes dus die ideale vrywilligers wat by niewinsgewende organisasies, wat dienssentrums vir bejaardes insluit, sinvol benut kan word. Volgens Hong, Iris en Ling (2010:70) is die gemiddelde aftree ouderdom vir vrouens tussen 50 en 55 jaar en vir mans tussen 55 en 60 jaar. Hierdie ouer volwassenes mag meer energie en tyd beskikbaar hê om by vrywillige aktiwiteite betrokke te raak.

Van Zyl (1992:2) stel dit duidelik dat die oorgang tussen die aktiewe werkfase en aftrede aanpassing meebring waarmee rekening gehou moet word, soos byvoorbeeld verminderde maandelikse inkomste, meer vryetyd, moontlike verandering van woonomgewing, verlies van vriende en hoër lewensverwagting. Dit is maar enkele probleme wat afgetredenes ervaar.

Vrywilligers is mense wat sonder finansiële vergoeding hul tyd, kennis en vermoëns beskikbaar stel vir die bevordering van 'n bepaalde saak (Krüger, 2008:18). Dienssentrums ervaar finansiële druk en kan nie altyd personeel betaal om te help met take in en om die dienssentrum nie. Gedurende 1995 was daar 385 geregistreerde dienssentrums vir bejaardes in Suid-Afrika, terwyl daar in 1998 slegs 188 was (South Africa, 2005:45). Die sinvolle en effektiewe benutting van afgetrede vrywilligers kan waardevol wees vir die afgetredene sowel as die dienssentrum.

Volgens die Independent Sector (2010), het vrywilligers waarde toegevoeg tot die Verenigde State van Amerika. In 2008 is die waarde van vrywilligers per uur teen $\$ 20.25( \pm \mathrm{R} 151.75)$ bereken. Hierdie beraming gee erkenning aan die miljoene individue wat hul tyd, talente en energie beskikbaar stel om ' $\mathrm{n}$ verskil te maak. Om vrywilligers te werf en te benut is een kant 
van die saak, maar belangriker is om hulle op te lei en vir ' $\mathrm{n}$ langtermyn betrokke te hou. Personeel van dienssentrums speel hierin ' $n$ prominente rol. Tang, Morrow-Howell \& Hong (2009:172) beweer dat indien meer niewinsgewende organisasies staatmaak op ouer volwasse vrywilligers om dienste te lewer, is dit belangrik om die vrywilligers vir langer tydperke te behou om kwaliteit dienste te kan verseker. Niewinsgewende organisasies is van so " $\mathrm{n}$ aard dat hulle die ouer volwasse vrywilligers se werkverwagtinge kan fasiliteer (Tang et al., 2009:172). Volgens Wilkinson en Cilliers (2004:78) sal 'n toegeruste vrywilliger op sy eie die taak wat die personeel van hom verwag, kan verrig. Personeel kan sodoende uitkom waarby hy/sy moet. ' $n$ Mens wat persoonlike groei ervaar is ' $n$ entoesiastiese mens wat ' $n$ hele groep kan inspireer (Wilkinson \& Cilliers, 2004:88).

Personeel weet nie altyd hoe om afgetrede vrywilligers sinvol te hanteer nie (Jansen van Rensburg, 2009:42). Gedurende 1998 is 'n studie deur United Parcel Service (UPS) Foundation (Stim \& Warner, 2008:89,90) gedoen waarvan die resultate daarop dui dat 41\% van die persone wat gereeld as vrywilligers werksaam was, dienste gestaak het as gevolg van die feit dat die welsynsorganisasie hulle tyd en talente nie voldoende benut het nie. Byna $60 \%$ van hierdie groep sou graag meer vrywillige werk wou doen indien hulle tyd beter benut sou word. Volgens Szala-Meneok (2009:509) is dit die ideaal dat diegene wat met ouer persone werk, die nodige kennis en ervaring van ouer persone sal hê. ' $n$ Sensitiwiteit in interpersoonlike verhoudings met die ouer persoon moet aan die dag gelê word.

Tydens ' $n$ seminaar wat deur Potchefstroom Dienssentrum vir Bejaardes (2009) vir afgetrede vrywilligers en personeel van dienssentrums en aftree-oorde aangebied is, het 43 respondente (75\%) deur middel van vraelyste aangedui dat daar 'n opleidingsprogram ontwikkel moet word vir personeel oor die effektiewe benutting en bestuur van vrywilligers. Volgens ' $n$ mededeling van Eckley (2010), voorsitter vir Help Seniors, is daar geen bemagtigingsprogram vir personeel en afgetrede vrywilligers beskikbaar nie en lê die studieveld braak.

\section{NAVORSINGSVRAAG}

Vanuit bogenoemde probleemstelling spruit die volgende navorsingsvrae.

- Wat die profiel van dienssentrums en die personeel in diens van dienssentrums is, die dienste wat die dienssentrum lewer en of hulle van afgetrede vrywilligers gebruik maak?

- Watter waarde hou afgetrede vrywilligers vir die personeel van dienssentrums in en watter take word deur hulle verrig?

- Wat verwag die personeel van dienssentrums van die afgetrede vrywilligers en moontlike frustrasies wat hulle ervaar?

- Wat dink personeel hoe behoort hulle teenoor afgetrede vrywilligers op te tree en oor watter eienskappe en vaardighede behoort personeel oor te beskik wat met afgetrede vrywilligers werk?

\section{DOEL VAN DIE ONDERSOEK}

Die doel van hierdie artikel is om ' $\mathrm{n}$ profiel van dienssentrums (in ' $\mathrm{n}$ radius van 150 kilometer rondom Potchefstroom) te kry wat met afgetrede vrywilligers werk, ' $n$ behoeftebepaling te doen onder personeel van dienssentrums vir bejaardes ten einde vas te stel of hulle van afgetrede vrywilligers se dienste gebruik, watter take die vrywilligers verrig en wat die stremminge is wat hulle ervaar ten opsigte van die benutting van vrywilligers. 


\section{Doelwitte}

\section{Doelwit 1}

Om vas te stel wat die profiel is van die dienssentrums wat by die studie betrek is, ' $\mathrm{n}$ profiel van die personeel betrokke by die dienssentrums, watter dienste die dienssentrums lewer en of hulle van afgetrede vrywilligers gebruik maak.

\section{Doelwit 2}

Om vas te stel watter waarde afgetrede vrywilligers vir die personeel van dienssentrums vir bejaardes inhou en watter take die vrywilligers verrig.

\section{Doelwit 3}

Om vas te stel wat die personeel van dienssentrums van die afgetrede vrywilligers verwag asook die frustrasies wat die personeel ten opsigte van die vrywilligers ervaar.

\section{Doelwit 4}

Om vas te stel wat die personeel dink oor hoe hulle teenoor die vrywilligers moet optree en om vas te stel wat die eienskappe en vaardighede is waaroor die personeel van dienssentrums moet beskik wat met afgetrede vrywilligers werk.

\section{SENTRAAL TEORETIESE STELLING}

Die omset in vrywilligers kan verlaag en tot voordeel van beide die dienssentrum en die afgetrede persoon strek, indien hul tyd en kundigheid meer effektief deur die personeel aangewend word.

\section{NAVORSINGSMETODOLOGIE}

Die intervensienavorsingsmodel (D \& D model) soos in De Vos et al. (2005:392-407) uiteengesit, is benut. Die fases van die model wat op hierdie artikel van toepassing is, is:

Fase 1: probleemontleding en projek beplanning en

Fase 2: versameling van inligting en samestelling soos gesien in tabel 1.

TABEL 1

INTERVENSIENAVORSINGSMODEL: FASE 1 EN FASE 2

\begin{tabular}{|c|c|}
\hline FASE 1 & FASE 2 \\
\hline Probleemontleding en projekbeplanning & Versameling van inligting en samestelling \\
\hline Identifisering en betrokkenheid van kliënt & 1. Benutting van bestaande inligtingsbronne \\
\hline $\begin{array}{l}\text { Verkryging van toegang en samewerking van } \\
\text { die omgewing }\end{array}$ & 2. Bestudeer natuurlike voorbeelde \\
\hline $\begin{array}{l}\text { Identifiseer dit waaroor die gemeenskap besorgd } \\
\text { is }\end{array}$ & $\begin{array}{l}\text { 3. Identifiseer funksionele elemente van } \\
\text { suksesvolle modelle }\end{array}$ \\
\hline $\begin{array}{l}\text { Analiseer die geïdentifiseerde aspekte waaroor } \\
\text { die gemeenskap besorgd is }\end{array}$ & \\
\hline Stel doelwitte en mikpunte & \\
\hline
\end{tabular}

Bogenoemde tabel (Tabel 1) lig die eerste twee fases van die intervensienavorsingsmodel duidelik uit. 


\section{Deelnemers}

Die ondersoek het betrekking op die 25 personeellede van die agt dienssentrums in ' $\mathrm{n}$ radius van 150 kilometers rondom Potchefstroom. Enige personeellid van die betrokke dienssentrums kon deelneem aan die ondersoek. Die agt dienssentrums wat hierby ingesluit is val in die Noordwes, Vrystaat en Gauteng provinsies.

\section{FIGUUR 1 \\ BETROKKE DIENSSENTUMS}

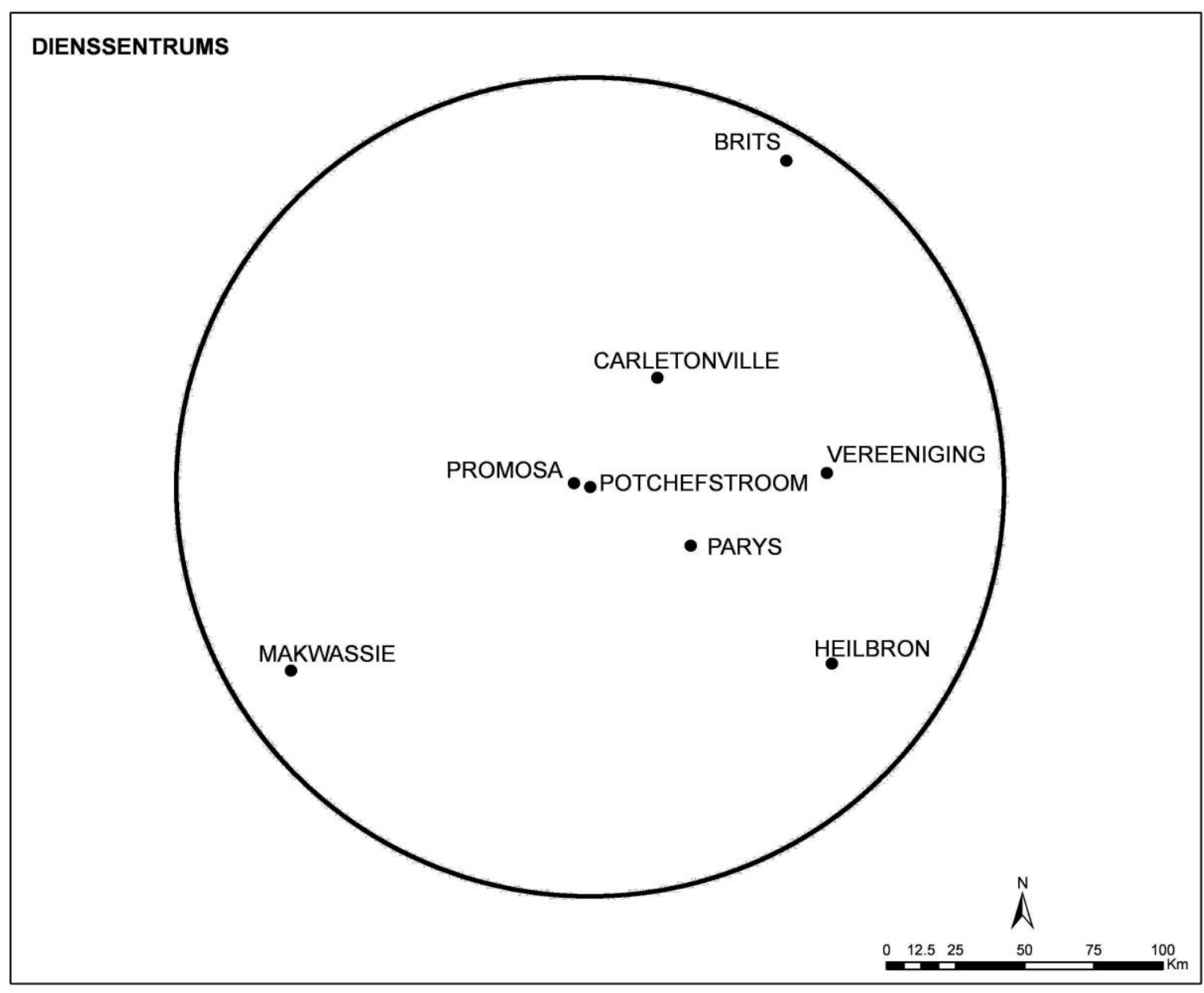

Figuur 1 dui die dienssentrums sowel as hul name aan en waar hulle geleë is.

\section{Meetinstrumente}

Data is by personeel ingesamel deur ' $n$ selfopgestelde meetinstrument wat die navorser gehelp het om die fokusgroep en in diepte onderhoudvoering te lei. Greeff (2005:292) vermeld dat die skedule waardevol is as dit gebruik word vir kwalitatiewe navorsing waar gefokus word op sekere belangrike areas, waar ruimte gelaat word vir buigbaarheid. Die meetinstrument is opgestel met oop- en geslotevrae. In diepte onderhoudvoering help om van die rykste en doeltreffendste data te bekom (Strydom, 2000:124-131; Strydom \& Delport, 2005:332).

\section{Prosedure}

Die opnameprosedure, kwantitatiewe meting sowel as kwalitatiewe meting is tydens die ondersoek benut. Opname word omskryf as die ondersoekmetode waarvolgens data uit ' $\mathrm{n}$ verteenwoordigende steekproef ingesamel word sodat die veranderlikes van toepassing op 
groot en klein populasies sal wees (Babbie, 2010:254-294; Bailey, 1994:110). 'n Voortoetsing van die selfopgestelde meetinstrument is tydens ' $\mathrm{n}$ seminaar vir afgetrede vrywilligers gedurende 2009 gedoen. Aldus Babbie (2010:267) is die voortoetsing van ' $n$ vraelys baie belangrik, want dit sluit onduidelike vrae of die verskillende interpreterings van vrae uit. Persone wat vir die opnameprosedure geselekteer is, is telefonies genader ten einde instemming tot deelname te bekom. Nadat die respondente hul toestemming verleen het, is " $n$ skrywe gerig wat kortliks agtergrond bied oor die omvang van die studie. Vyf en twintig personeellede van die agt dienssentrums het aan die ondersoek deelgeneem.

By die gebruik van kwantitatiewe data word veranderlikes teenoor mekaar opgeweeg en met die kwalitatiewe data word indiepte gevoelens en belewenisse van die deelnemers ondersoek (Ivankova, Creswell \& Clark, 2007:259). Die metodes dra by ten einde die triangulering van data en aanvullende data te kan verkry. Al die personeellede van die agt dienssentrums wat geselekteer is, kon aan die ondersoek deelneem.

\section{Etiese aspekte}

Etiese goedkeuring is van die Etiekkomitee van die Potchefstroomkampus van die NoordwesUniversiteit verkry. Deelname van die ondersoekgroep was te alle tye vrywillig, ingeligte toestemming is verkry om te verseker dat die ondersoekgroep wel vrywilliglik deelneem en te eniger tyd aan die ondersoek kon onttrek (Universiteit van Pretoria, 1999:29-30). Aldus SzalaMeneok (2009:508) is die volgende drie etiese beginsels naamlik respek vir mense, welwillendheid en regverdigheid van groot belang wanneer met ouer persone gewerk word. Hierdie beginsels is deurlopend in ag geneem met hierdie navorsingstudie. Die prosedure sowel as die doel van die ondersoek is verduidelik, respondente is dus nie mislei nie. Alle persoonlike inligting is anoniem en konfidensieel hanteer (Marlow, 2001:25-26; Strydom, 2005:57-67).

\section{Dataverwerking}

Die kwantitatiewe data uit die selfontwerpte meetinstrument is met die SAS rekenaarprogram (2005) deur die Statistiese Konsultasiediens van die Noordwes-Universiteit verwerk. Die navorser het self die kwalitatiewe data verwerk deur oopvrae te analiseer volgens Tesch se benadering (Poggenpoel, 1998:343-344).

\section{OMSKRYWING VAN BEGRIPPE}

Begrippe wat herhaaldelik in die navorsingsverslag gebruik word, word soos volg omskryf:

\section{Afgetrede vrywilliger}

Aldus die navorser self, is ' $n$ afgetrede vrywilliger ' $n$ persoon ouer as 60 jaar wat uit eie keuse sonder finansiële vergoeding bereid is om by ' $\mathrm{n}$ niewinsgewende organisasie betrokke te raak, ten einde behulpsaam te wees met die lewering van maatskaplike dienste of aktiwiteite wat deur die organisasie gelewer word.

\section{Aftrede}

Myburgh (1999) som aftrede op as 'n voorval of gebeurtenis wat groot veranderinge in 'n persoon se lewe teweeg bring - 'n status wat 'n persoon bereik in opvolging van aftrede met 'n verskil in sosiale posisie, maar ook met eie unieke rolle, verwagtinge en verantwoordelikhede, 'n proses wat in fases plaasvind en die aanvaarding van 'n nuwe situasie wat bepaalde uitdagings bied, en moontlik die oorkoming van probleme behels. Aftrede is in wese 'n komplekse sosiale fenomeen wat elkeen se lewe raak. 
Uit bogenoemde omskrywing van aftrede is dit egter duidelik dat daar daadwerklike veranderinge plaasvind wanneer ' $n$ mens uit jou voltydse beroep tree. Daar moet bepaalde aanpassings gemaak word wat op sy beurt sal bepaal hoe gelukkig en tevrede die afgetredene met hierdie nuwe lewensfase sal wees.

\section{Dienssentrum}

Die Vaktaalkomitee vir Maatskaplike Werk (1995:10) omskryf 'n dienssentrum as 'n nieresidensiële fasiliteit vir dienslewering aan bejaarde persone asook die voorsiening van geleenthede vir gesellige verkeer en deelname aan ontspannings-, opvoedkundige en kulturele programme.

Swanepoel (1995:114) en Van Donkersgoed (1992:145) omskryf 'n dienssentrum as die middelpunt vanwaar gemeenskapsdienste deur 'n welsyns- of ander goedgekeurde instansie tot voordeel van of aan bejaardes gelewer word. Dienssentrums het ten doel om alle noodsaaklike ondersteunende hulpdienste te lewer en ontspanningsgeleenthede te skep wat bejaardes in staat stel om so lank moontlik selfstandig, onafhanklik, menswaardig en as volwaardige lede van die gemeenskap te bly.

Aldus die navorser self, is ' $n$ dienssentrum ' $n$ nie-residensiële fasiliteit vanwaar gemeenskapsdienste deur ' $n$ niewinsgewende organisasie gelewer word. Die doel hiermee is om die nodige ondersteunende hulpdienste te lewer, verrykende-, sosiale- geestelike- en kulturelegeleenthede te skep wat ouer persone in staat stel om so lank moontlik selfstandig en onafhanklik as volwaardige lede van die gemeenskap aktief te kan funksioneer en verouder.

\section{Vrywilliger}

Volgens Barker (2003:458) is 'n vrywilliger 'n persoon wat bereid is om te dien, gewoonlik sonder finansiële vergoeding.

Roux (2008) beskryf die vrywilliger as 'n persoon wat sonder geldelike vergoeding en sonder om in 'n formele werknemer-werkgewerverhouding staan, welsynsdienste onderneem of daarmee behulpsaam is.

Vrywilligers word verder deur (Krüger, 2010:36) omskryf as mense uit verskillende beroepe wat sonder finansiële vergoeding hul tyd, kennis en vermoëns vir die bevordering van ' $n$ bepaalde saak beskikbaar stel.

Vrywilligers raak gewoonlik by meer as een aktiwiteit van ' $\mathrm{n}$ dienssentrum betrokke (Jansen van Rensburg \& Strydom, 2010:388).

\section{Vrywilligewerk}

Volgens Barker (2003:458) is vrywilligewerk die mobilisasie en gebruik van onbetaalde individue en groepe om menslike dienste te lewer.

Aldus Krüger (2010:36) is vrywilligewerk ' $n$ wonderlike geleentheid om diensbaar te wees, ' $n$ bydrae te lewer tot die welsyn van die gemeenskap en self verryk te word met kennis oor bejaardesorg.

\section{BEVINDINGE}

In hierdie afdeling word die bevindinge van die ondersoek per opskrif hanteer. 
Profiel van die dienssentrums vir bejaardes

\section{Bestaansjare}

\section{LYNKAART 1 \\ BESTAANSJARE VAN DIE DIENSSENTRUMS}

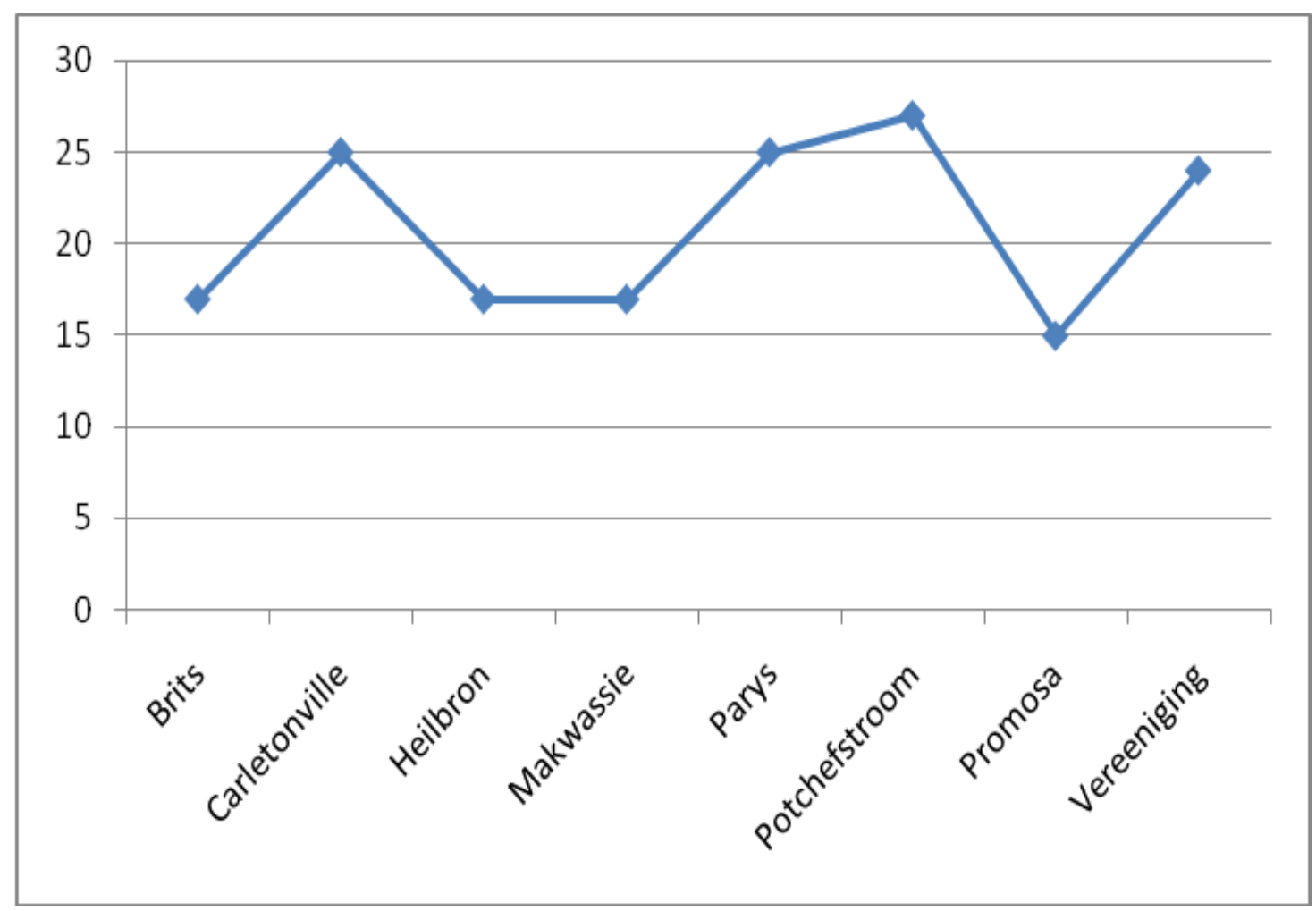

Uit bogenoemde is die gemiddelde bestaansjare van die betrokke dienssentrums 22 jaar. Die jongste is Happy Hearts Dienssentrum in Promosa (Potchefstroom), wat 15 jaar oud is en die oudste dienssentrum is Potchefstroom Dienssentrum wat 27 jaar oud is. Personeellede van die betrokke dienssentrums wat in beheer van die dienssentrums is, is $62.5 \%$ ouer as 60 jaar. Dit beteken dat vyf van die agt dienssentrums bestuur word deur persone ouer as 60 jaar.

\section{Bestuur van die dienssentrums}

TABEL 2

DEUR WIE DIE DIENSSENTRUMS BESTUUR WORD

\begin{tabular}{|c|c|c|}
\hline Outonoom & Kerk & SAVF \\
\hline $37.5 \%$ & $37.5 \%$ & $25 \%$ \\
\hline
\end{tabular}

Tabel 2 wys duidelik uit dat $37.5 \%$ van die dienssentrums wat deel van die navorsing uitmaak, outonoom is wat beteken dat hulle ' $\mathrm{n}$ eie selfstandige bestaan voer. Die ander $37.5 \%$ van die dienssentrums word deur twee verskillende kerk denominasies bestuur en dan is daar verder 25\% dienssentrums wat deur die Suid-Afrikaanse Vroue Federasie bestuur word.

\section{Personeellede}

Die agt dienssentrums het gedurende 2010 gesamentlik 100 personeellede in diens. Potchefstroom het 77 betaalde personeellede. Die gemiddelde aantal personeellede tussen die ander sewe dienssentrums is dus drie persone. Hierdie personeel sluit skoonmakers en 
tuinwerkers van die dienssentrums in. Die gemiddelde ouderdom van die 25 personeellede wat deel van die navorsing was, is 46 jaar. Die jongste is 26 jaar en die oudste 65 jaar.

Dienste wat die betrokke dienssentrums lewer

TABEL 3

DIENSTE SOOS DEUR DIE ONDERSKEIE DIENSSENTRUMS GELEWER WORD.

\begin{tabular}{|l|c|l|c|l|c|}
\hline Dienste & $\begin{array}{c}\text { Aantal } \\
\text { sentrums }\end{array}$ & \multicolumn{1}{|c|}{ Dienste } & $\begin{array}{c}\text { Aantal } \\
\text { sentrums }\end{array}$ & \multicolumn{1}{|c|}{ Dienste } & $\begin{array}{c}\text { Aantal } \\
\text { sentrums }\end{array}$ \\
\hline Sosiale klub & 7 & Etes & 4 & Tuishulp & 2 \\
\hline Uitstappies & 7 & Koor & 4 & Vingerbord & 1 \\
\hline Vervoer & 6 & Bingo & 3 & Handwerk & 1 \\
\hline Trimgim/Sangala & 6 & Jukskei & 3 & Houtsneewerk & 1 \\
\hline Kliniekdienste & 5 & $\begin{array}{l}\text { Mediese } \\
\text { hulpmiddels }\end{array}$ & 3 & Tuinhulp & 1 \\
\hline Toere & 5 & $\begin{array}{l}\text { Maatskaplike } \\
\text { werk }\end{array}$ & 3 & Lyndans & 1 \\
\hline Aanry-etes & 5 & Brug & 2 & Orkes & 1 \\
\hline Rummykub & 5 & Tuisverpleging & 2 & Tuissorg & 1 \\
\hline Haarkappery & 4 & Rolbal & 2 & & \\
\hline
\end{tabular}

Sosiale klubs en uitstappies word deur $87.5 \%$ dienssentrums aangebied, vervoer en trimgim of sangala oefeninge word deur $75 \%$ van die dienssentrums aangebied en kliniekdienste, toere, aanry-etes en rummykub word deur $62.5 \%$ dienssentrums aangebied. Dienssentrums spits hulle oor die algemeen toe op sosiale en ontspanningdienste (sekondêre dienste), terwyl dit die primêre dienste, noodsaaklike dienste is wat nodig is om die ouer persoon in staat te stel om so lank moontlik selfstandig te kan funksioneer.

Aldus Pierson en Thomas (2010:372) kan effektiewe dagversorgingsdienste, tuisversorging en voetversorging goeie gesondheid ondersteun, maar onafhanklikheid vra meer as dit. Vrees vir misdaad, swak vervoer en ontoeganklike geboue benadeel ook onafhanklikheid en keuses vir die ouer persone.

\section{Gebruikmaking van afgetrede vrywilligers}

Al die dienssentrums wat deel van die navorsing uitgemaak het, het aangedui dat hulle wel van afgetrede vrywilligers gebruik maak. Sewe dienssentrums het van 337 vrywilligers wat ouer as 60 jaar is gebruik gemaak en 130 was jonger as 60 jaar. Een dienssentrum het geen aanduiding gegee van die vrywilligers waarvan hulle gebruik maak nie.

Aldus Hong et al. (2010:63-64) is vrywillige werk deur ouer persone in China, 'n relatiewe nuwe begrip. Daar is weinig studies gedoen oor vrywillige werk wat deur ouer persone verrig word in Mainland China.

Van Meyer (2010) is van mening dat die vernaamste beginsels van vrywillige werk die volgende moet wees:

- Vrywillige werk strek tot voordeel vir die gemeenskap en die vrywilliger;

- Vrywillige werk is gratis; 
- Vrywillige werk is altyd 'n vrye keuse;

- Vrywillige werk is 'n wettige wyse waarop mense kan deelneem aan die aktiwiteite van die gemeenskap;

- Vrywillige werk is die hulpmiddel vir individue of groepe om menslike-, omgewings- en sosiale behoeftes aan te spreek;

- Vrywillige werk is ' $\mathrm{n}$ aktiwiteit wat slegs in die niewinsgewende sektor plaasvind;

- Vrywillige werk bevorder menseregte en gelykheid, en

- Vrywillige werk respekteer die regte, waardigheid en kultuur van die ander.

\section{Die waarde wat afgetrede vrywillige werk inhou}

Jonker (2010) skryf dat sy die afgelope maande eers besef het wat die waarde van vrywillige werkers is. Volgens haar sou sy sonder die staatmakers nie suksesvol in haar projekte wees nie. Vrywilligers offer hul tyd, geld en ander hulpbronne op om ander in nood by te staan. Zuma (2010) spreek sy dankbaarheid teenoor die vrywilligers uit wat soveel mense inspireer om diegene wat die swaarste deur die armoede krisis getref word deur moeilike tye te help.

Malgas (2004) berig aan Die Burger dat vrywilligers die ruggraat van niewinsgewende organisasies is en ' $\mathrm{n}$ aansienlike bydrae lewer tot die sosio-ekonomiese ontwikkeling van SuidAfrika. Daar is baie min sentrums vir vrywilligers en die regering het onlangs begin om klem te lê op die belangrikheid van vrywillige werk. Daries (1999:119) is van mening dat afgetredenes waardevolle tyd het om aan die gemeenskap te bestee. Die waarde van vrywilligers is dat hulle die betaalde personeel tyd bespaar, dat hulle ' $n$ verlengstuk van hulpbronne is, en dat hulle meer persoonlike aandag aan ouer persone kan bestee vanweë die feit dat hulle meer tyd tot hulle beskikking het as die betaalde personeel.

Die personeel van die betrokke dienssentrums het die volgende waardes van vrywilligers aangedui:

- Ses respondente het gesê dat die vrywilligers die personeeltake en werksdruk verlig.

- Drie het gesê dat afgetrede vrywilligers van onskatbare waarde is.

- Twee dui aan dat die vrywilligers altyd hulpvaardig is.

- Vrywillige werk dra by tot die menswaardigheid van die afgetrede vrywilligers.

- Vrywillige werk laat hulle nodig voel.

- Dit is ' $\mathrm{n}$ kostebesparing vir die dienssentrum.

- Vrywillige werkers hou die arms van die personeel hoog.

- Hulle lewer ' $n$ bydrae tot die sukses van die dienssentrum.

- Vrywilligers skep ' $n$ positiewe atmosfeer.

Uit bogenoemde is dit egter duidelik dat afgetrede vrywilligers van groot waarde vir niewinsgewende organisasies is, en in die besonder dienssentrums vir bejaardes.

\section{Take wat deur afgetrede vrywilligers verrig word}

Die take wat deur die afgetrede vrywilligers binne die betrokke dienssentrums verrig word, word kortliks hieronder weergegee.

\section{Aankope}

Vrywilligers help met die aankoop van produkte, meublement, toerusting en skryfbehoeftes. 


\section{Administrasie}

Take waarmee hulle behulpsaam is, is onder andere tikwerk, taalkundige versorging, beantwoording van die telefoon, skryf van notules en skryf van lief- en leedkaartjies aan medelede.

\section{Beheer en bestuur}

Lede van die dienssentrums dien op rade en komitees. Hulle bedien die bestuurslede van die dienssentrum met raad en advies.

\section{Fondswerwing}

Vrywilligers help met die verkope van kaartjies, voorbereiding van etes, die opskep en bediening van etes tydens fondswerwingsprojekte.

\section{Handwerk}

Maak handwerk items om vir die dienssentrum te verkoop om fondse in te samel, soom tafeldoeke vir die dienssentrum om en maak vatlappies vir die gebruik in die kombuise.

\section{Help met die lewering van dienste}

Van die afgetrede vrywilligers is by die maatskaplike werker betrokke om eensame bejaardes te besoek en te bemoedig. Hulle is behulpsaam met die aflewering van aanry-etes, help met die kontroles tydens middag etes en bedien mede bejaardes tydens etes. By die gesondheidsdepartement help hulle met bloeddrukkontroles, onderneem gesondheidsvoorligtingspraatjies en besoek siek en verswakte bejaardes. Afgetrede vrywilligers help met die vervoer van lede na die dokters, hospitale, na die sakegebied en na die dienssentrum.

Volgens Pierson en Thomas (2010:371) bestaan die neiging om minder dienste vir ouer persone aan te bied teen hoër kostes. Hierdie stelling beklemtoon die dringendheid om van vrywilligers se dienste gebruik te maak ten einde die nodige dienste aan die ouer persone te lewer teen bekostigbare pryse.

\section{Nutsman}

Klein takies in en om die dienssentrum word deur bejaarde mans verrig. Hulle help met die instandhouding van voertuie en toerusting.

\section{Sosialisering}

Afgetrede vrywilligers help as afrigters of instrukteurs by sosialiseringsaktiwiteite, tree as aktiwiteitsleiers op, hou bywoningsregisters in stand en help met die saamstel van sosiale programme.

\section{Voorbereiding van lokale}

Met funksies wat deur die dienssentrum gereël of aangebied word, help die afgetrede vrywilligers met die voorbereiding van die lokaal, hulle dek tafels, doen blomme versierings en help weer met die opruiming.

Golden (2010:22) is van mening dat dit goed vir jou gesondheid is om vrywillige werk te verrig. Dit beur jou op, laat jou glimlag en verhoog jou algemene goedvoel gevoel. Sy haal vir Abraham Lincoln aan wat sê: "as you grow older you will discover that you have two hands. One for helping yourself, the other for helping others."

'n Groep mense dien sonder vergoeding, op ' $\mathrm{r}$ raad en ander help as vrywilligers met projekte. Die waarde van vrywillige en gratis dienste van finansiële raadgewers, prokureurs, bourekenaars, sakemanne en ander kundiges is onberekenbaar, so skryf Burger (2009). 


\section{Verwagtinge ten opsigte van afgetrede vrywilligers}

Personeel van dienssentrums verwag die volgende van afgetrede vrywilligers: om eerlik te wees, terugvoering te gee, die beeld van die dienssentrum uit te dra, positief te wees, lojaliteit, dat vrywilligers soms nee sal sê, dat hulle ' $n$ kwaliteit diens sal lewer, dat hulle sal vra indien hulle nie weet nie, hul beste sal gee, te alle tye vriendelik sal wees, so akkuraat moontlik sal wees in die uitvoering van take. Verdere verwagtinge is ondersteuning aan die personeel, " $n$ openheid, stiptelikheid, dat daar ' $n$ vertrouensverhouding sal wees, dat vrywilligers sal help omsien na programme, hulp aanbied, diensbaarheid, inisiatief sal neem, om in " $n$ span saam te kan werk, geduld, simpatie, dat hulle hul kennis en ervaring met personeel sal deel, bereid sal wees om opleiding te ontvang, verantwoordelikheid te aanvaar en take met liefde uit te voer.

\section{Frustrasies wat personeel ervaar}

Frustrasies wat die personeel van dienssentrums met afgetrede vrywillige werkers ervaar is onder andere:

- dat vrywilligers nie altyd beskikbaar is nie en op kort kennisgewing kanselleer;

- vrywilligers wat nie doen wat van hulle gevra word nie en veeleisend is met versoeke;

- onervare helpers wat nie raad aanvaar nie, ongeduldig of negatief is;

- vrywilligers wat misbruik maak van die dienssentrum se telefoon, kuier en gesels wanneer die druk dit nie toelaat nie;

- wanneer vrywilligers nie aan die personeel terugvoering gee nie;

- vrywilligers wat nie op eie inisiatief kan werk nie;

- as afgetrede vrywilligers nie toesien dat dinge onder hul toesig gedoen word nie, en

- hul stadige tempo.

Hoe personeel teenoor afgetrede vrywilligers behoort op te tree

\section{HISTOGRAM 1 \\ BELANGRIKE KARAKTEREIENSKAPPE}

Die ses belangrikste aspekte wat deur die personeel van dienssentrums uitgewys is, is:

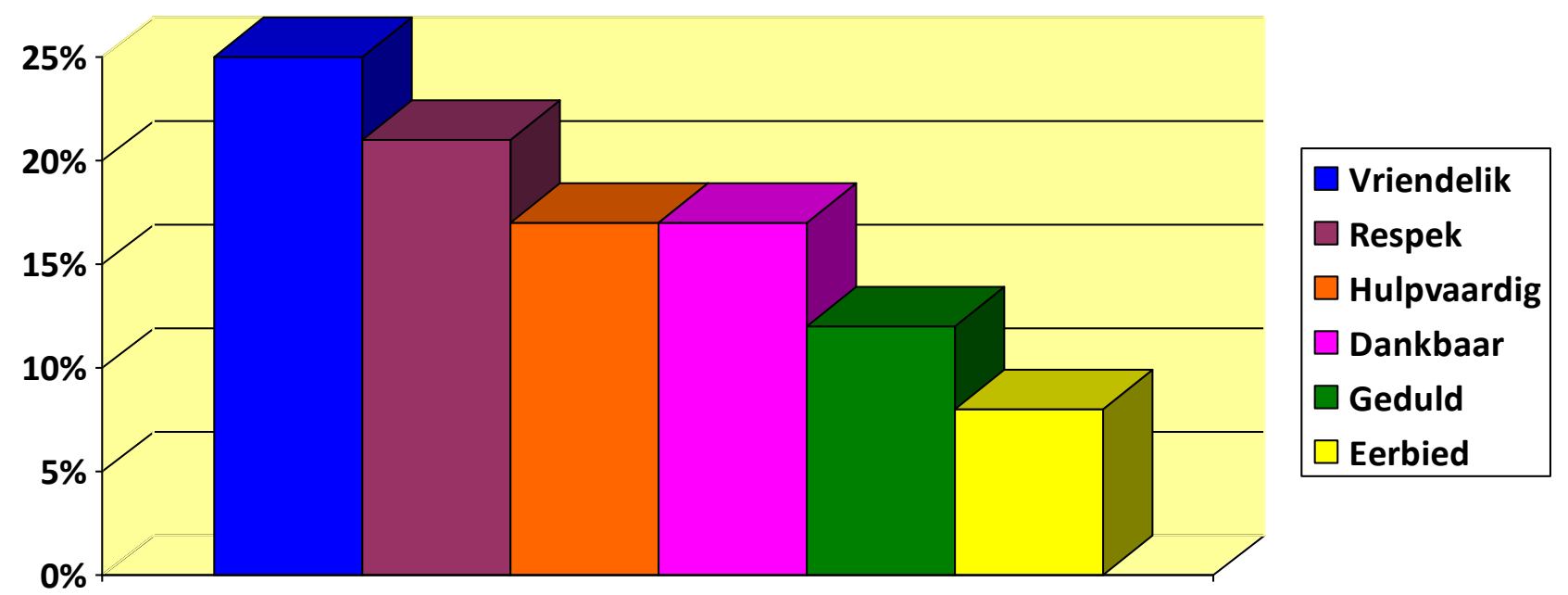

Afgetrede vrywilligers geniet hul dienslewering net soveel meer as die personeel vriendelik is, hulle met respek behandel, hulp verleen waar dit nodig is, dankbaarheid teenoor die afgetrede vrywilligers betoon, geduldig is en hulle met eerbied behandel. 
Eienskappe en vaardighede waaroor personeel moet beskik

TABEL 4

BELANGRIKE EIENSKAPPE EN VAARDIGHEDE VAN PERSONEEL

\begin{tabular}{|l|l|l|}
\hline Duidelike opdragte gee & Sterk morele waardes & Aanvaar ouer persone \\
\hline Kennis van ouer persone & Selfvertroue & Betroubaar \\
\hline Doelgerig & Behulpsaam & Erkenning gee \\
\hline Opgeruimde persoonlikheid & Konflik kan hanteer & In 'n span kan saamwerk \\
\hline Empatie & Geduld & Kennis van vrywilligers \\
\hline Eerlikheid & Kommunikasievaardighede & Liefdevol \\
\hline Deernis & Rustige persoonlikheid & Luistervaardighede \\
\hline Vriendelikheid & Moet kan koördineer & Respek \\
\hline
\end{tabular}

Al bogenoemde eienskappe en vaardighede is as baie belangrik tot noodsaaklik deur die respondente aangedui.

\section{Algemene inligting}

Die respondente het op die volgende vrae almal met 'n ja of beslis ja geantwoord.

Voel u dat vrywilligers ' $n$ verskil in ander mense se lewens maak?

Voel u dat vrywilligers aan die organisasie se werksdruk 'n verskil maak?

Geniet u dit om met vrywillige werkers te werk?

Benut u die vrywilliger se tyd effektief?

Sou u sê dat personeel weet hoe om met afgetrede vrywilligers te werk?

Is opdragte vanaf personeel duidelik?

Dink u daar moet ' $\mathrm{n}$ opleidingsprogram ontwikkel word vir personeel oor die effektiewe benutting en bestuur van vrywillige werkers?

\section{BEVINDINGE}

Die jongste definisie wat gevind kon word oor wat ' $\mathrm{n}$ dienssentrum vir bejaardes is, is in 1995 geskryf. Uit hierdie studie blyk dit belangrik te wees om te besef dat die dienssentrums wat in die ondersoek betrek is al ' $\mathrm{n}$ gemiddeld van 22 jaar bestaan. Vyf van die agt bestuurders van die onderskeie dienssentrums is ouer as 60 jaar. Hulle is self dus al ouer persone. Daar is bevind dat die dienssentrums wat die meeste dienste en aktiwiteite aanbied beide outonome dienssentrums is. Die dienssentrums (Potchefstroom Dienssentrum vir Bejaardes uitgesluit) het slegs ' $n$ gemiddeld van drie personeellede in hul diens. Dit beklemtoon die groot behoefte en aanvraag van afgetrede vrywilligers wat die personeel van hulp moet wees.

Die benutting van afgetrede vrywilligers is vir die personeel van groot waarde. Sewe van die agt dienssentrums lê sterker klem op sekondêre of sosiale dienste eerder as die primêre of noodsaaklike ondersteunende dienste. Die take wat aangedui word wat deur die vrywilligers verrig word dra daartoe by dat personeel by ander take en verantwoordelikhede kan uitkom. Die verwagtinge wat die personeel van dienssentrums koester rondom die afgetrede vrywilliger is realisties. Frustrasies wat die personeel ervaar ten opsigte van die benutting van vrywilligers kan in die bemagtigingsprogram vir afgetrede vrywilligers aangespreek word. Hierdie 
frustrasies is deel van die risiko's wat personeel bereid moet wees om te neem wanneer van die dienste van vrywilligers gebruik gemaak word. Die ses belangrikste aspekte van hoe personeel teenoor afgetrede vrywilligers behoort op te tree is die ideaal. Die respondente het ' $n$ eensgesindheid oor die eienskappe en vaardighede waaroor personeel wat met afgetrede vrywilligers werk, moet beskik.

\section{AANBEVELINGS}

Die volgende aanbevelings kan gemaak word:

- Die definisie van 'n dienssentrum soos omskryf deur die navorser self, moet opnuut by die besture en personeel van dienssentrums gevestig word.

- Terugvoering moet aan alle personeellede van dienssentrums gegee word oor watter waarde afgetrede vrywilligers vir hulle kan inhou en die take wat deur hulle verrig kan word.

- Deur middel van ' $\mathrm{n}$ bemagtigingsprogram kan leiding aan personeellede gegee word oor hoe hulle teenoor afgetrede vrywilligers behoort op te tree en oor die verlangde eienskappe en vaardighede waaroor hulle behoort te beskik.

\section{SAMEVATTING}

In hierdie artikel is die profiel van die betrokke dienssentrums ondersoek, wat insluit die ouderdom van die dienssentrums, die personeel in diens van dienssentrums se ouderdomme, deur watter instansie die dienssentrums bestuur word, maak hulle gebruik van afgetrede vrywillige werkers, watter dienste die dienssentrums lewer en die aktiwiteite wat hulle aanbied. Ondersoek is ingestel na die waarde wat afgetrede vrywilligers vir die dienssentrum en personeel inhou sowel as die take wat deur die vrywilligers verrig word. Daar is verder gekyk na die personeel se verwagtinge van afgetrede vrywilligers en moontlike frustrasies wat die personeel ten opsigte van die vrywilliger mag ervaar. Ten slotte is personeel gevra hoe hulle dink personeel behoort op te tree teenoor die afgetrede vrywilliger en die eienskappe en vaardighede waaroor personeel behoort te beskik wat met afgetrede vrywilligers werk.

\section{BIBLIOGRAFIE}

BABBIE, E. 2010. The practice of social research $\left(12^{\text {th }}\right.$ ed). Belmont: Wadsworth.

BARKER, R.L. 2003. The social work dictionary $\left(5^{\text {th }}\right.$ ed). Washington: NASW Press.

BAILEY, K.D. 1994. Methods of social research. New York: The Free Press.

BURGER. 2009. Jan Kriel Instituut. [Web]: http://www1.givengain.com/cause_data/images 11312/Nuusbrief_Maart_2009.pdf [Datum van gebruik: 22/10/2010].

DARIES, J. 1999. Older volunteers - a vital link in community care. In: The South African Council for the Aged. National Conference 11-13 August 1999. Cape Town: 8-9.

DEPARTMENT OF SOCIAL DEVELOPMENT. 2005. Policy for older persons. Pretoria: Staatsdrukkers.

DE VOS, A.S. 2005. Intervention research. In: DE VOS, A.S., STRYDOM, H., FOUCHÉ, C.B. \& DELPORT, C.S.L. (eds) Research at grass roots: for the social science and human service professions. Pretoria: Van Schaik Publishers: 392-407.

ECKLEY, S.C.A. 2010. Mondelinge mededeling aan outeur, Pretoria. 
GOLDEN, M. 2010. Volunteering can make a difference. Plus 50, (5/3):22-23.

GREEFF, M. 2005. Information collection: interviewing. In: DE VOS, A.S., STRYDOM, H., FOUCHÉ, C.B. \& DELPORT, C.S.L. (eds) Research at grass roots: for the social science and human service professions. Pretoria: Van Schaik Publishers: 286-313.

HONG, L., IRIS, C. \& LING, X. 2010. Factors associated with volunteerism among community-living older adults in urban China. Social Development Issues. Alternative Approaches to Global Human Needs, 32(1):62-75.

INDEPENDENT SECTOR. 2010. Value of volunteer time. [Online] Available: http://www. independentsectororg/programs/research/volunteertime.html [Accessed: 13/02/2010].

IVANKOVA, N.V., CRESWELL, J.W. \& CLARK, V.L.P. 2007. Foundations and approaches to mixed methods research. In: MAREE, K. (ed) First steps in research. Pretoria: Van Schaik Publishers: 253-282.

JANSEN VAN RENSBURG, S.M. 2009. Die rol van die afgetrede vrywilliger in die funksionering van Potchefstroom Dienssentrum vir Bejaardes. Potchefstroom: NoordwesUniversiteit. (MA(MW) Verhandeling)

JANSEN VAN RENSBURG, S. \& STRYDOM, H. 2010. Profiel en betrokkenheid van afgetrede vrywilligers by ' $\mathrm{n}$ niewinsgewende organisasie. Social Work/Maatskaplike Werk, 46(3):381-394.

JONKER, H. 2010. Vervulling. [Web]: http://www.hispeople.co.za/downloads/RR_Nov\% 20STD\% 20Bank\% 20Mapreneur.pdf [Datum van gebruik: 22/10/2010].

KRÜGER, E. 2008. Vrywillige werkers in bejaardesorg. Plus 50, (3/4):18-20.

KRÜGER, E. 2010. Vrywillige werkers in bejaardesorg. Plus 50, (5/5):36.

MALGAS, M. 2004. Malgas lê tuig neer. [Web]: http://152.111.1.87/argief/berigte/dieburger/ 2004/06/10/MO/04/02.html [Datum van gebruik: 24/10/2010].

MARLOW, C. 2001. Research methods for generalist social work $\left(3^{\text {rd }} \mathrm{ed}\right)$. Wadsworth: Brooks/Cole.

MYBURGH, M. 1999. Voorbereiding vir aftrede: 'n Bedryfsmaatskaplike werk ondersoek. Pretoria: Universiteit van Pretoria. (MA(MW) Verhandeling)

NTUSI, N. \& FERREIRA, M. 2004. South African doctors and elderly patients. Bold, 15(1):3-13.

PIERSON, J. \& THOMAS, M. 2010. Dictionary of social work. The definitive A to $\mathbf{Z}$ of social work and social care. Glasgow: Bell and Bain Ltd.

POGGENPOEL, M. 1998. Data analysis in qualitative research. In: DE VOS, A.S., STRYDOM, H., FOUCHÉ, C.B. \& DELPORT, C.S.L. (eds) Research at grass roots: for the social science and human service professions. Pretoria: Van Schaik Publishers: 334-353.

POTCHEFSTROOM DIENSSENTRUM VIR BEJAARDES. 2009. Seminaar vir afgetrede vrywilligers. 15 Oktober 2009. Potchefstroom.

ROUX, A.A. 2008. Opleidingskursus vir vrywilligers van Potchefstroom Dienssentrum vir Bejaardes. (Voordrag gelewer as deel van die opleidingskursus vir vrywilligers betrokke by maatskaplike werk op 30 Januarie 2008.) Potchefstroom. (Ongepubliseer) 
SAS INSTITUTE INC. 2005. SAS/STAT, Release 9.1. [Online] Available: www.sas.com.

SOUTH AFRICA. 2005. Department of Social Development. South African policy for older persons. Pretoria: Government Printers.

STIM, R. \& WARNER, R. 2008. Retire happy: what you can do now to guarantee a great retirement. Berkeley: Nolo.

STATISTICS SOUTH AFRICA. 2001. Census. [Online] Available: http://www. statssa.gov.za/census01/Census/Dialog/Saveshow.asp [Accessed: 29/03/2008].

STRYDOM, H. 2000. Maatskaplikewerk-navorsing (MWK 321/411). Potchefstroom: PU vir CHO. (Diktaat)

STRYDOM, H. 2005. Ethical aspects of research in the social sciences and human service professions. In: DE VOS, A.S., STRYDOM, H., FOUCHÉ, C.B. \& DELPORT, C.S.L. (eds) Research at grass roots: for the social science and human service professions. Pretoria: Van Schaik Publishers: 56-70.

STRYDOM, H. \& DELPORT, C.S.L. 2005. Sampling and pilot study in qualitative research. In: DE VOS, A.S., STRYDOM, H., FOUCHÉ, C.B. \& DELPORT, C.S.L. (eds) Research at grass roots: for the social science and human service professions. Pretoria: Van Schaik Publishers: 327-332.

SWANEPOEL, L. 1995. Die mishandeling van bejaardes in Heidedal - 'n maatskaplikewerkperspektief. Bloemfontein: Universiteit van die Oranje-Vrystaat. (MSocScVerhandeling)

SZALA-MENEOK, K. 2009. Ethical research with older adults. In: MERTENS, D.M. \& GINSBERG, P.E. (eds) Social research ethics. London: Sage Publications: 507-517.

TANG, F., MORROW-HOWELL, N. \& HONG, S. 2009. Institutional facilitation in sustained volunteering among older adult volunteers. Social Work Research, 33(3):172-182.

UNITED STATES CENSUS BUREAU. 2009. Census. [Online] Available: http:www. census.gov/ipc/www/idb/region.php [Accessed: 12/03/2010].

UNIVERSITEIT VAN PRETORIA. 1999. Kode vir navorsingsetiek. [Web] http://www. ais.up.ac.za/research/kode_etiek.pdf [Datum van gebruik: 16/04/2010].

VAKTAALKOMITEE VIR MAATSKAPLIKE WERK. 1995. Nuwe woordeboek vir maatskaplike werk. Kaapstad: CTP Book Printers.

VAN DONKERSGOED, M.L. 1992. 'n Maatskaplikewerk-bestuursmodel ter ondersteuning van ' $n$ geselekteerde groep bejaardes. Bloemfontein: Universiteit van die Oranje-Vrystaat. (MSocSc Verhandeling)

VAN MEYER, I. 2010. Mandela Day at the Tygerberg Service Centre. [Online] Available: http://www.capegateway.gov.za/eng/pubs/speeches/2010/jul/201751 [Accessed: 03/11/2010].

VAN ZYL, C.C. 1992. 'n Maatskaplikewerk-model vir aftredebeplanning. Bloemfontein: Universiteit van die Oranje Vrystaat. (MsocSc Verhandeling).

WILKINSON, B. \& CILLIERS, A. 2004. Die droomgewer vir leiers. Wellington: Lux Verbi. 
ZUMA, J.G. 2010. Staatsrede. (sy eksellensie JG Zuma, president van die republiek van SuidAfrika tydens die gesamentlike sitting van die parlement, Kaapstad. [Web]: http://www.info. gov.za/speaches/2010/10022610151003.htm [Datum van gebruik: 22/10/2010].

Me Sanet Jansen van Rensburg, Potchefstroom Dienssentrum vir Bejaardes; Prof Herman Strydom, Skool vir Psigososiale Gedragswetenskappe: Vakgroep Maatskaplike Werk, Potchefstroomkampus van die Noordwes-Universiteit, Potchefstroom, SuidAfrika. 